\title{
Incidence of West Nile Virus in Birds Arriving in Wildlife Rehabilitation Centers in Southern Spain
}

\author{
Guillermo López, Miguel Ángel Jiménez-Clavero,, Ana Vázquez, ${ }^{3}$ Ramón Soriguer, \\ Concha Gómez-Tejedor, ${ }^{4}$ Antonio Tenorio, ${ }^{5}$ and Jordi Figuerola ${ }^{1}$
}

\begin{abstract}
West Nile virus (WNV) is a neurotropic mosquito-transmitted flavivirus that in Eurasia, Africa, and the Americas primarily affects birds and secondarily other vertebrates. WNV has caused frequent massive episodes of wild bird mortality during its expansion throughout the Americas, and has become a regulating factor in the population dynamics of many wild bird species. On the other hand, WNV-related mortalities in wild birds have rarely been reported in the Mediterranean Basin despite its well-documented circulation, and only sporadic outbreaks in horses have been documented. The causes underlying this contrasting epidemiological pattern have never been properly described. An initial suggestion is that Mediterranean and American strains possess different pathogenicities, whereas an alternative view proposes that WNV-related disease and mortalities may have been overlooked in Europe. To test these hypotheses, between 2004 and 2006 in southern Spain we sampled tissue from 119 wild bird carcasses to detect WNV and other flaviviruses, as well as blood from 227 wild birds arriving in wildlife rehabilitation centers to test for WNV seroprevalence. No flavivirus was found in the tissue samples. The prevalence of WNV-neutralizing antibodies was $2.2 \%$, similar to that of 800 healthy birds of the same species that were captured in the field. Our results suggest that WNV circulation during the study period did not result in any detectable effects in terms of bird morbidity or mortality.
\end{abstract}

Key Words: Birds—Infectious disease-Mediterranean—Outbreak—Spain—West Nile Virus.

\section{Introduction}

$\mathbf{W}$ EST NiLe VIRUS (WNV) is a zoonotic mosquito-borne flavivirus (family Flaviviridae) that belongs to the Japanese encephalitis serocomplex. Birds are recognized as one of major vertebrate hosts of WNV, although WNV also has the potential to infect other vertebrates, including mammals (Hayes 1989). WNV is a neurotropic virus that provokes acute neurological disease in birds, which can cause a variety of symptoms such as ataxia, disorientation, tremors, and convulsions (Steele et al. 2000, Erdélyi et al. 2007, Beasley and Barrett 2009). Humans and horses are considered accidental dead-end hosts, and infection in these species is associated with a febrile illness that can progress to a lethal encephalitis with symptoms such as cognitive dysfunction and flaccid paralysis (Sejvar et al. 2003, Castillo-Olivares and Wood 2004, Hayes and Gubler 2006).
WNV is mainly maintained in nature in an enzootic cycle between mosquitoes and birds (Komar 2003, Hayes et al. 2005), in which seasonality is linked to vector ecology (Zeller and Schuffenecker 2004). Despite not being host-specific (Beasley and Barrett 2009), WNV incidence and prevalence differ among avian species and populations, and are primarily determined by intrinsic ecological factors (Kilpatrick et al. 2007a, Savage et al. 2007, Figuerola et al. 2008). Mosquito species of the genus Culex are the most competent WNV vectors participating in the maintenance of the cycle (Hamer et al. 2008, Reisen et al. 2008), although a large number of other mosquito species also have the potential for transmitting the virus (Turell et al. 2005). Besides vector-mediated transmission, direct bird-to-bird transmission has also been documented (Banet-Noach et al. 2003).

Since WNV was first identified from a human case of febrile illness in Uganda in 1937, it has been found to occur in Africa

\footnotetext{
${ }^{1}$ Estación Biológica de Doñana, Seville, Spain.

${ }^{2}$ Instituto Nacional de Investigación y Tecnología Agraria y Alimentaria, Valdeolmos, Spain.

${ }^{3}$ Instituto de Salud Carlos III, Majadahonda, Spain.

${ }^{4}$ Laboratorio Central de Veterinaria, Algete, Spain.

${ }^{5}$ Instituto de Salud Carlos III, Majadahonda, Spain.
} 
and Eurasia, and to produce some sporadic outbreaks in horses and humans (Murgue et al. 2001a, Gubler 2007). Further, since 1999, when it was first detected in the United States (Gubler 2007, Artsob et al. 2009), WNV has rapidly expanded throughout the Americas and caused recurrent outbreaks in birds (Mostashari et al. 2003, Kilpatrick et al. 2007b), horses (Trock et al. 2001), and humans (Lindsey et al. 2008, Artsob et al. 2009), and is currently considered to be an important emerging pathogen. Due to its pathogenicity, WNV has a negative impact on the population dynamics of many resident American bird populations (LaDeau et al. 2007). By contrast, the sanitary impact of WNV in Europe and Africa seems to be low, and most of the sporadic outbreaks in these continents have been detected in horses (Murgue et al. 2001b, Autorino et al. 2002, Schuffenecker et al. 2005, Cabre et al. 2006). In the Mediterranean Basin, no massive WNV outbreaks have ever been detected in wild birds (Zeller and Schuffenecker 2004). Two major nonexclusive hypotheses are used to explain these differing epidemiological patterns in WNV: (1) the pathogenicity or resistance of birds to the virus strains currently circulating throughout the Americas may be different in the Mediterranean Basin; (2) avian mortalities caused by WNV may have been overlooked given the traditionally low impact of WNV on human health in Europe. In fact, WNV-related avian mortality was not considered an indicator of viral activity until the 1998 epidemics in Israel and subsequently in North America (Malkinson et al. 2002, LaDeau et al. 2007).

In Spain, some authors have provided evidence of local circulation of WNV in recent years (Bofill et al. 2006, BernabéuWittel et al. 2007, Figuerola et al. 2007a, 2007b, Kaptoul et al. 2007), and the virus has been detected in captive large eagles in inland Iberia (Höfle et al. 2008, Jiménez-Clavero et al. 2008). Despite this documented circulation in the area, no WNV outbreak involving large numbers of dead or ill wild birds has ever been detected in the Iberian Peninsula. To study the impact of WNV on wild avian populations in southern Spain, we sampled a large number of wild birds in rehabilitation centers in Andalusia during a period of known WNV circulation in the region. We analyzed birds of different taxons inhabiting both wetland and dry inland areas (Fig. 1). To be sure that WNV was circulating in the study area and, if so, whether this circulation was provoking an increase in morbidity or mortality in local birds, we conducted (1) molecular analyses to detect WNV and other flaviviruses in the tissue of dead birds, and (2) serology tests to detect WNV antibodies in living individuals. If circulating WNV was a cause of morbidity or mortality in birds, we would expect to find polymerase chain reaction (PCR)-positive birds among the arrivals in the rehabilitation centers. Alternatively, if WNV was not a cause of increased morbidity or mortality, we would only expect to detect serology-positive but not PCR-positive individuals.

\section{Materials and Methods}

Between November 2004 and February 2006, we sampled 346 wild birds of 33 different species (see Table 1), both alive $(n=227)$ and dead $(n=119)$, in the official network of rehabilitation centers belonging to the Department of the Environment of the Andalusian Regional Government (Andalusia, southern Spain). These rehabilitation centers treat wild birds found injured or sick throughout Andalusia and release them back into the wild. Thus, we expected to find a higher WNV prevalence in these individuals than in healthy wild birds. We divided the sampled species into six groups: raptors ( $n=72$ alive, 0 dead), owls ( $n=67$ alive, 12 dead), ducks ( $n=34$ alive, 32 dead), herons and storks ( $n=28$ alive, 26 dead), waders and gulls ( $n=23$ alive, 37 dead), and other species ( $n=3$ alive, 12 dead). All groups included both migratory and resident species.

A sample of about $1 \mathrm{~mL}$ of blood was taken from the brachial or jugular vein of all living sampled individuals using $2 \mathrm{~mL}$ syringes with $25 \mathrm{G}$ needles. Subsequently, blood was deposited in a vial without anticoagulant and $3 \mathrm{~h}$ later was centrifuged in an Eppendorf ${ }^{\circledR}$ Minispin ${ }^{\circledR}$ centrifuge to separate the serum from the blood cells. The sera thus obtained were employed to run a micro-virus-neutralization test in 96-well plates. WNV strain Eg101 and the E6 clone of Vero cells used for virus propagation were obtained from Hervé Zeller (Institut Pasteur de Lyon). This technique, already described in Figuerola et al. (2007a), provides high specificity for $\mathrm{WNV}$, and also can provide a light cross-reactivity with closely related flaviviruses. Blood cells were stored at $-80^{\circ} \mathrm{C}$ until subsequent analyses. Additionally, we determined the antibody prevalence in healthy wild birds captured in different localities of the Doñana National Park. Data for some of these individuals have already been reported in Figuerola et al. (2008). To ensure that the data from both sets of birds were comparable, we only considered information from birds of species analyzed in both the rehabilitation centers and captured between November 2004 and February 2006 ( $n=800$ individuals belonging to seven species). The prevalence between wild (presumably) healthy and captured ill individuals was compared with the GENMOD procedure of SAS 9.2 (SAS Institute Inc. 2008) in a generalized linear model, with the number of individuals with antibodies as the response variable, the number of individuals analyzed as the binomial denominator of the response variables, and species as a repeated subject. A binomial error distribution with a logit link was used for the analysis.

A total of 349 tissue samples from different organs collected from dead birds were analyzed for RT-nested-PCR to detect possible infection. To search for WNV, brain $(n=98)$, cardiac muscle $(n=31)$, and feather pulp $(n=15)$ were the main tissues sampled. However, other tissues were also sampled when possible to detect (1) possible WNV infections (Steele et al. 2000) and (2) potential infection by other flaviviruses located in the different target organs. Thus, samples were also collected from liver $(n=27)$, spleen $(n=22)$, lung $(n=27)$, kidney $(n=27)$, ovary $(n=9)$, oviduct $(n=6)$, testicle $(n=12)$, thyroid $(n=19)$, parathyroid $(n=14)$, pancreas $(n=21)$, blood cells $(n=19)$, and the Fabricius bursa $(n=2)$. Tissue samples were placed in liquid nitrogen at $-196^{\circ} \mathrm{C}$ immediately after collection and kept until analysis. The nucleic acid was extracted using Rneasy Mini Kit (Qiagen, Izasa, Spain) following the manufacturer's instructions. The extracted RNA was analyzed using a generic RT-nested-PCR, which detects both generic flaviviruses and specific WNV sequences (Sánzhez-Seco et al. 2005). Both positive and negative controls of the PCR functioned correctly.

\section{Results}

The overall WNV seroprevalence of our sample was 2.2\%, with 5 positive individuals out of the total of 227 analyzed 
Table 1. Serology Results of the West Nile Virus Micro-Virus-Neutralization Test Performed Between November 2004 and February 2006 on 227 Live Birds Sampled in the Andalusian Wildlife Rehabilitation Centers, and on 800 Healthy Individuals Sampled in the Doñana Area

\begin{tabular}{|c|c|c|c|c|c|}
\hline \multirow[b]{2}{*}{ Species } & \multirow[b]{2}{*}{$R / M$} & \multicolumn{2}{|c|}{ Rehabilitation centers } & \multicolumn{2}{|c|}{ Healthy birds in the field } \\
\hline & & $\begin{array}{c}\text { Positive at } \\
1: 10 / 1: 20(\mathrm{n})\end{array}$ & $\begin{array}{c}\text { Prevalence at } \\
1: 20(\%)\end{array}$ & $\begin{array}{c}\text { Positive at } \\
1: 10 / 1: 20(\mathrm{n})\end{array}$ & $\begin{array}{c}\text { Prevalence at } \\
1: 20(\%)\end{array}$ \\
\hline Falco tinnunculus & $\mathrm{R}$ & $2 / 2(22)$ & 9 & & \\
\hline Gyps fulvus & $\mathrm{R}$ & 0/0 (16) & 0 & & \\
\hline Falco naumanni & M & 1/0 (15) & 0 & & \\
\hline Buteo buteo & $\mathrm{R}$ & $0 / 0(4)$ & & & \\
\hline Milvus migrans & $\mathrm{M}$ & $0 / 0(4)$ & & & \\
\hline Circaetus gallicus & M & $0 / 0(3)$ & & & \\
\hline Milvus milvus & $\mathrm{M}$ & $0 / 0(2)$ & & & \\
\hline Hieraaetus pennatus & $\mathrm{M}$ & $1 / 0(2)$ & & & \\
\hline Circus aeruginosus & $\mathrm{R}$ & $0 / 0(1)$ & & & \\
\hline Pernis apivorus & M & $0 / 0(1)$ & & & \\
\hline Accipiter gentilis & $\mathrm{R}$ & $1 / 0(1)$ & & & \\
\hline Aegypius monachus & $\mathrm{R}$ & $0 / 1(1)$ & & & \\
\hline Total raptors & & $5 / 3(72)$ & 4 & & \\
\hline Athene noctua & $\mathrm{R}$ & $0 / 0(20)$ & 0 & & \\
\hline Bubo bubo & $\mathrm{R}$ & $2 / 0(18)$ & 0 & & \\
\hline Tyto alba & $\mathrm{R}$ & $0 / 0(16)$ & 0 & & \\
\hline Strix aluco & $\mathrm{R}$ & $1 / 0(12)$ & 0 & & \\
\hline Asio otus & $\mathrm{M}$ & $0 / 0(1)$ & & & \\
\hline Total owls & & $3 / 0(67)$ & 0 & & \\
\hline Anas platyrhynchos & $\mathrm{R}$ & $0 / 0(25)$ & 0 & 6/4 (195) & 2 \\
\hline Aythya nyroca & $\mathrm{R}$ & $0 / 0(7)$ & 0 & $0 / 0(1)$ & \\
\hline Marmoronetta angustirostris & $\mathrm{R}$ & $0 / 0(2)$ & & $1 / 0(2)$ & \\
\hline Total ducks & & $0 / 0(34)$ & 0 & $7 / 4(198)$ & 2 \\
\hline Ciconia ciconia & M & $2 / 2(21)$ & 10 & $5 / 3(21)$ & 14 \\
\hline Bubulcus ibis & $\mathrm{R}$ & $0 / 0(3)$ & & $1 / 1(12)$ & 8 \\
\hline Ardea cinerea & $\mathrm{M}$ & $0 / 0(1)$ & & $0 / 0(1)$ & \\
\hline Ardeola ralloides & $\mathrm{M}$ & $0 / 0(1)$ & & & \\
\hline Platalea leucorodia & $\mathrm{R}$ & $0 / 0(1)$ & & & \\
\hline Plegadis falcinelus & $\mathrm{R}$ & $0 / 0(1)$ & & & \\
\hline Total herons and storks & & $2 / 2(28)$ & 7 & $1 / 1(13)$ & 8 \\
\hline Fulica atra & $\mathrm{R}$ & 2/0 (13) & 0 & $264 / 114(569)$ & 20 \\
\hline Larus ridibundus & M & $0 / 0(7)$ & 0 & & \\
\hline Burhinus oedicnemus & $\mathrm{R}$ & $0 / 0(1)$ & & & \\
\hline Himantopus himantopus & $\mathrm{R}$ & $0 / 0(1)$ & & & \\
\hline Larus genei & M & 0/0 (1) & & & \\
\hline Total waders and gulls & & $2 / 0(23)$ & 0 & $264 / 114(569)$ & 20 \\
\hline Corvus corax & $\mathrm{R}$ & $0 / 0(2)$ & 0 & & \\
\hline Coturnix coturnix & $\mathrm{M}$ & $0 / 0(1)$ & 0 & & \\
\hline Total others & & 0/0 (3) & 0 & & \\
\hline Total & & $12 / 5(227)$ & 2 & $272 / 119(780)$ & 15 \\
\hline
\end{tabular}

Intraspecific prevalences are indicated when sample size was larger than five individuals. The migratory behavior of every species is indicated ( $R$, resident; $M$, migratory).

birds (two white storks Ciconia ciconia, two common kestrels Falco tinnunculus, and one black vulture Aegypius monachus). Four positives had titers between 1:20 and 1:80, and a single individual (a kestrel) had a titer of 1:320. Seroprevalence in this sample was not significantly different from that obtained from healthy birds captured in the field $\left(\chi^{2}=2.93\right.$, $p=0.09$; rehabilitation center mean \pm standard error of the mean: $2.78 \% \pm 13.81 \%$; field: $15.23 \% \pm 13.04 \%$ ). The apparent large differences in the mean were due to one species, the common coot Fulica atra, which was very prevalent among the field samples $(20 \%)$ but not in the rehabilitation centers $(0 \%)$, probably due to the different geographical origin of the samples. If we exclude this species from the analyses, the differences in antibody prevalence in the rehabilitation centers $(3.39 \% \pm 14.66 \%)$ and the field $(3.45 \% \pm 8.50 \%)$ is nil $\left(\chi^{2}=0.00, p=0.97\right)$. A further 12 of these positive birds had titers of $1: 10$, probably due to either a previous contact with the virus, a cross reaction with another WNV closely related flavivirus, an incipient infection with $\mathrm{WNV}$, or even an interindividual difference in the immune response. The proportion of individuals displaying titers of 1:10 or higher was $19 \%$ for white storks, $18 \%$ for common kestrels, and 15\% for common coots. Griffon vultures, little owls, and mallards showed no prevalence despite the large number of samples analyzed. Herons and storks $(14 \%)$ and raptors $(11 \%)$ were the groups that had the highest 


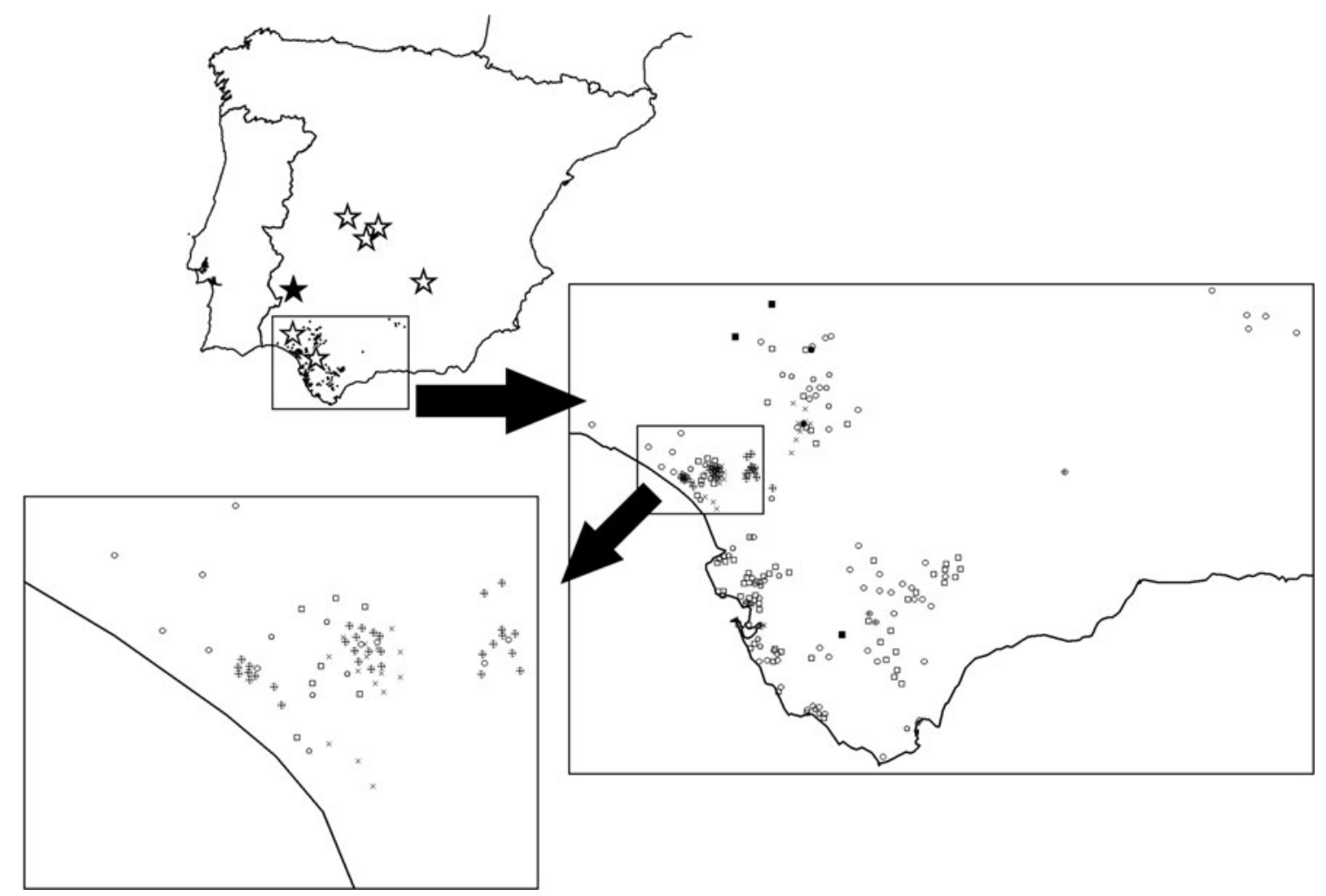

FIG. 1. Geographical origin of the wild live birds sampled in the Andalusian rehabilitation centers in this study. Raptors are represented as squares, owls as circles, herons and storks as pentagons, ducks as crossed circles, waders and gulls as crosses, and other species as dotted circles. Inside the study area, the Doñana wetland area is depicted separately. Bold symbols represent West Nile virus-seropositive cases. Stars represent locations where West Nile virus circulation has been reported in Spain: solid stars represent reports in humans (Kaptoul et al. 2007) and bold stars in birds and horses (Figuerola et al. 2007b, Jiménez-Clavero et al. 2007, Höfle et al. 2008, Jiménez-Clavero et al. 2008).

seroprevalence, whereas there were no positive cases at all in ducks.

Neither WNV nor any other flavivirus genomes were found in any of the tissue samples analyzed. In other work carried out on mosquitoes in the same region using the same methodology as this study, flavivirus sequences have been found (Aranda et al. 2009, Sánchez-Seco et al. 2009).

\section{Discussion}

WNV circulation in the Mediterranean Basin has only rarely been associated with wild bird mortality (Dauphin et al. 2004, Zeller and Schuffenecker 2004, Jourdain et al. 2007), an exception being the outbreak occurred in Israel that resulted in detectable mortalities of up to $40 \%$ in some stork flocks (Malkinson et al. 2002). Despite the fact that other studies have reported a lack of detectable mortality in the field, this study is the first to specifically analyze the presence of WNV and antibodies against WNV in ill and injured birds arriving in rehabilitation centers. As expected, we did find WNV antibodies in the birds arriving rehabilitation centers, but their prevalence was no higher than that found in healthy birds captured in the field. This result confirms that the virus was circulating in the avian population during the study period. However, we found neither WNV nor any other related flavivirus in the tissues of a large sample of wild birds with health problems in southern Spain. The lack of WNV in tissue suggests that WNV was not a cause of increased morbidity or mortality in birds entering wildlife rehabilitation centers, despite the circulation of WNV in the area. Although isolated cases with related mortality were described during the same period (Höfle et al. 2008, Jiménez-Clavero et al. 2008), our results suggest that the WNV strains currently circulating in the area are not likely to have any effect on avian population dynamics, unlike the situation in the Americas (LaDeau et al. 2007). Recently, experimental infections have confirmed the lower pathogenicity of these WNV isolates on mice under laboratory conditions (Sotelo et al. in press), and similar results have also been obtained using a new avian model for wild birds (Sotelo et al. unpublished data). The 2.2\% seroprevalence obtained in our study is slightly lower than those previously found in Spain (3.8\%-10.4\%; Figuerola et al. 2007a, Figuerola et al. 2008, López et al. 2008) and in other European countries, such as France (4.8\%; Jourdain et al. 2008) and the Czech Republic (5.9\%; Hubálek et al. 2008). In contrast to the findings in Europe, seroprevalences found in the Americas have usually found to be higher: that is, $25.6 \%$ in Argentina (Díaz et al. 2008) or $1.8 \%$ to $95 \%$ in the United States (Medica et al. 2007, Wilcox et al. 2007, Dusek et al. 2009, Nemeth et al. 2009).

The interspecific differences in seroprevalence observed in this study, above all those found in species occupying the same habitat (such as mallards and coots in the field, $2 \%$ vs. $20 \%$ antibody prevalence), could be due to intraspecific dif- 
ferences in (1) susceptibility to WNV, (2) WNV-vector biting preferences, and (3) differences in avian ecology that result in a different exposure to the vectors (Kilpatrick et al. 2007a, $2007 b$ ). Identifying the causes of these interspecific differences in our study is difficult due to the large geographical heterogeneity in the origin of the samples, which means that the individual birds sampled would have been exposed to varying abundances of mosquitoes and different risks of contact with the virus. However, the possibility that the lower prevalence of antibodies in mallards as opposed to coots was due to an increased mortality in WNV-infected mallards could be discarded given that (1) we failed to detect WNV in the brain of 32 dead mallards taken in this study and (2) the results of Marra et al. (2004) described that none of 12 experimentally inoculated mallards developed signs of clinical illness and that the infection cleared up in less than 7 days. In terms of the migratory behavior of the individuals with antibodies, out of the five seropositive cases, only white storks are partially migratory, whereas kestrels and black vultures are both resident. Moreover, four out of five positives were found during winter (December-February), including both white storks (which suggest that they were resident). These results demonstrate that the circulation of WNV took place in the study area and allow discarding that the prevalence found in this study is only due to infections in Africa of migrating birds. The spatial distribution of the seropositive birds also suggests that WNV has been circulating not only in Doñana, as has been previously reported in southern Spain (Figuerola et al. 2007b), but also in other localities in the Seville and Cádiz areas.

\section{Conclusion}

On the basis of birds arriving in the rehabilitation centers, our results suggest that WNV circulation in southwest Andalusia has not led to any increased morbidity or mortality among wild birds.

\section{Acknowledgments}

The Spanish Health Ministry, via its Thematic Research Net "EVITAR," funded our research. The PAIDI Research groups RNM 118 (RC and GL) and RNM 351 (JF) of the Junta de Andalucía and the European Commission (Contract 010284-2, Emerging Diseases in a Changing European Environment project contribution EDEN0208) also provided financial support. The Red de CREAs of the Andalusian Government allowed us to take samples and also provided help with the sampling. Juan Carlos Capuz, Nuria Viqueira, Isabel Molina, and Beatriz Sánchez helped with the fieldwork.

\section{Disclosure statement}

No competing financial interests exist.

\section{References}

Aranda, C, Sánchez-Seco, MP, Cáceres, F, Escosa, R, et al. Detection and monitoring of mosquito Flaviviruses in Spain between 2001 and 2005. Vector Borne Zoonot 2009; 9:171-178.

Artsob, H, Gubler, DJ, Enria, DA, Morales, MA, et al. West Nile virus in the New World: trends in the spread and proliferation of West Nile virus in the Western Hemisphere. Zoonoses Public Health 2009; 56:357-369.
Autorino, GL, Battisti, A, Deubel, V, Ferrari, G, et al. West Nile virus epidemic in horses, Tuscany region, Italy. Emerg Infect Dis 2002; 8:1372-1378.

Banet-Noach, C, Simanov, L, Malkinson, M. Direct (non-vector) transmission of West Nile virus in geese. Avian Pathol 2003; 32:489-494.

Beasley, DWC, Barrett, ADT. Virulence of West Nile virus in different animal hosts. In: Diamond, MS, ed. West Nile Encephalitis Virus Infection: Viral Pathogenesis and the Host Immune Response. New York: Springer, 2009:137-153.

Bernabéu-Wittel, M, Ruiz-Pérez, M, del Toro, MD, Aznar, J, et al. West Nile virus past infections in the general population of Southern Spain. Enferm Infecc Microbiol Clin 2007; 25:559-560.

Bofill, D, Domingo, C, Cardeñosa, N, Zaragoza, J, et al. Human West Nile virus infection, Catalonia, Spain. Emerg Infect Dis 2006; 12:1163-1164.

Cabre, O, Grandadam, M, Marie, JL, Gravier, P, et al. West Nile virus in horses, sub-Saharan Africa. Emerg Infect Dis 2006; 12:1958-1960.

Castillo-Olivares, J, Wood, J. West Nile virus infection of horses. Vet Res 2004; 35:467-483.

Dauphin, G, Zientara, S, Zeller, H, Murgue, B. West Nile: worldwide current situation in animals and humans. Comp Immunol Microbiol 2004; 27:343-355.

Díaz, AL, Komar, N, Visintin, A, Dantur, J, et al. West Nile virus in birds, Argentina. Emerg Infect Dis 2008; 14:689-691.

Dusek, RJ, McLean, RG, Kramer, LD, Ubico, SR, et al. Prevalence of West Nile virus in migratory birds during spring and fall migration. Am J Trop Med Hyg 2009; 81:1151-1158.

Erdélyi, K, Ursu, K, Ferenczi, E, Szeredi, L, et al. Clinical and pathologic features of lineage 2 West Nile virus infections in birds of prey in Hungary. Vector Borne Zoonot 2007; 7:181188.

Figuerola, J, Jiménez-Clavero, MA, Rojo, G, Gómez-Tejedor, C, Soriguer, R. Prevalence of West Nile virus neutralizing antibodies in colonial aquatic birds in southern Spain. Avian Pathol 2007a; 36:209-212.

Figuerola, J, Jiménez-Clavero, MA, López, G, Rubio, C, et al. Size matters: West Nile virus neutralizing antibodies in resident and migratory birds in Spain. Vet Microbiol 2008; 132:39-46.

Figuerola, J, Soriguer, R, Rojo, G, Gómez-Tejedor, C, JiménezClavero, MA. Seroconversion in wild birds and local circulation of West Nile virus, Spain. Emerg Infect Dis 2007b; 13:1915-1917.

Gubler, DJ. The continuing spread of West Nile virus in the Western Hemisphere. Clin Infect Dis 2007; 45:1039-1046.

Hamer, GL, Kitron, UD, Brawn, JD, Loss, SR, et al. Culex pipiens (Diptera: Culicidae): a bridge vector of West Nile virus to humans. J Med Entomol 2008; 45:125-128.

Hayes, CG. West Nile fever. In: Monath, TP, ed. The Arboviruses: Epidemiology and Ecology. Boca Raton, FL: CRC Press, 1989: 59-88.

Hayes, EB, Gubler, DJ. West Nile virus: epidemiology and clinical features of an emerging epidemic in the United States. Annu Rev 2006; 57:181-194.

Hayes, HB, Komar, N, Nasci, RS, Montgomery, SP, et al. Epidemiology and transmission dynamics of West Nile virus disease. Emerg Infect Dis 2005; 11:1167-1173.

Höfle, U, Blanco, JM, Crespo, E, Naranjo, V, et al. West Nile virus in the endangered Spanish imperial eagle. Vet Microbiol 2008; 129:171-178.

Hubálek, Z, Halouzka, J, Juricová, Z, Sikutová, S, et al. Serologic survey of birds for West Nile flavivirus in southern Moravia (Czech Republic). Vector Borne Zoonot 2008; 8:659-666. 
Jiménez-Clavero, MA, Gómez-Tejedor, C, Rojo, G, Soriguer, R, Figuerola, J. Serosurvey of West Nile virus in equids and bovids in Spain. Vet Rec 2007; 161:212.

Jiménez-Clavero, MA, Sotelo, E, Fernández-Pinero, J, Llorente, F, et al. West Nile virus in golden eagles, Spain, 2007. Emerg Infect Dis 2008; 14:1489-1491.

Jourdain, E, Schuffenecker, I, Korimbocus, J, Reynard, S, et al. West Nile virus in wild resident birds, southern France, 2004. Vector Borne Zoonot 2007; 7:448-452.

Jourdain, E, Zeller, HG, Sabatier, P, Murri, S, et al. Prevalence of West Nile virus neutralizing antibodies in wild birds from the Camargue area, southern France. J Wildl Dis 2008; 44:766-771.

Kaptoul, D, Viladrich, PF, Domingo, C, Niubó, J, et al. West Nile virus in Spain: report of the first diagnosed case (in Spain) in a human with aseptic meningitis. Scan J Infect Dis 2007; 39:70-71.

Kilpatrick, AM, Daszak, P, Jones, MJ, Marra, PP, Kramer LD. Host heterogeneity dominates West Nile virus transmission. Proc R Soc B Biol Sci 2007a; 273:2327-2333.

Kilpatrick, AM, Ladeau, SL, Marra, PP. Ecology of West Nile virus transmission and its impact on birds in the western hemisphere. Auk 2007b; 124:1121-1136.

Komar, N. West Nile virus: epidemiology and ecology in North America. Adv Virus Res 2003; 61:185-234.

LaDeau, SL, Kilpatrick, AM, Marra, PP. West Nile virus emergence and large-scale declines of North American bird populations. Nature 2007; 447:710-713.

Lindsey, NP, Kuhn, S, Campbell, GL, Hayes, EB. West Nile virus neuroinvasive disease incidence in the United States, 20022006. Vector Borne Zoonot 2008; 8:35-40.

López, G, Jiménez-Clavero, MA, Gómez-Tejedor, C, Soriguer, R, Figuerda, J. Prevalence of West Nile virus neutralizing antibodies in Spain is related to the behavior of migratory birds. Vector Borne Zoonot Dis 2008; 8:615-621.

Malkinson, M, Banet, C, Weisman, Y, Pokamunski, S, et al. Introduction of West Nile virus in the Middle East by migrating white storks. Emerg Infect Dis 2002; 8:392-397.

Marra, PP, Griffing, S, Caffrey, C, Kilpatrick, AM, et al. West Nile virus and wildlife. Bioscience 2004; 54:393-402.

Medica, DL, Clauser, R, Bildstein, K. Prevalence of West Nile virus antibodies in a breeding population of American Kestrels (Falco sparverius) in Pennsylvania. J Wildl Dis 2007; 43:538-541.

Mostashari, F, Kulldorff, M, Hartman, JJ, Miller, JR, Kulasekera, $\mathrm{V}$. Dead bird clustering: a potential early warning system for West Nile virus activity. Emerg Infect Dis 2003; 9:641-646.

Murgue, B, Murri, S, Triki, H, Deubel, V, Zeller, G. West Nile in the Mediterranean basin: 1950-2000. Ann NY Acad Sci 2001a; 951:117-126.

Murgue, B, Murri, S, Zientara, S, Durand, B, et al. West Nile outbreak in horses in southern France, 2000: the return after 35 years. Emerg Infect Dis 2001b; 7:692-696.

Nemeth, NM, Dwyer, JF, Morrison, JL, Fraser, JD. Prevalence of antibodies to West Nile virus and other arboviruses among Crested Caracaras (Caracara cheriway) in Florida. J Wildl Dis 2009; 45:817-822.

Reisen, WK, Barker, CM, Fang, Y, Martínez, VM. Does variation in Culex (Diptera: Culicidae) vector competence enable out- breaks of West Nile virus in California? J Med Entomol 2008; 45:1126-1138.

Sánchez-Seco, MP, Rosario, D, Domingo, C, Hernández, L, Valdés, K, Guzmán, MG, Tenorio, A. Generic RT-nested-PCR for the detection of flaviviruses using degenerated primers and internal control followed by sequencing for specific identification. J Virol Methods 2005; 126:101-109.

Sánchez-Seco, MP, Vázquez, A, Collao, X, Hernández, L, et al. Surveillance of arboviruses in Spanish wetlands: detection of new flavi- and phleboviruses. Vector Borne Zoonot 2010; 10:203-206.

SAS Institute Inc. SAS/STAT 9.2 User's Guide. Cary, NC: SAS Institute Inc., 2008.

Savage, HM, Aggarwal, D, Apperson, CS, Katholi, CR, et al. Host choice and West Nile virus infection rates in blood-fed mosquitoes, including members of the Culex pipiens complex, from Memphis and Shelby County, Tennessee, 2002-2003. Vector Borne Zoonot 2007; 7:365-386.

Schuffenecker, I, Peyrefitte, CN, el Harrak, M, Murri, S, et al. West Nile virus in Morocco, 2003. Emerg Infect Dis 2005; 11:306-309.

Sejvar, JJ, Haddad, MB, Tierney, BC, Campbell, GL, et al. Neurologic manifestations and outcome of West Nile virus infection. J Am Med Assoc 2003; 290:511-515.

Sotelo, E, Fernandez-Pinero, J, Llorente, F, Agüero, M, et al. Characterization of West Nile virus isolates from Spain: new insights into the distinct West Nile virus eco-epidemiology in the Western Mediterranean. Virology 2009; 20:289-297.

Steele, KE, Linn, MJ, Schoepp, RJ, Komar, N, et al. Pathology of fatal West Nile virus infections in native and exotic birds during the 1999 outbreak in New York City, New York. Vet Pathol 2000; 37:208-224.

Trock, SC, Meade, BJ, Glaser, AL, Ostlund, EN, et al. West Nile virus outbreak among horses in New York state, 1999 and 2000. Emerg Infect Dis 2001; 7:745-747.

Turell, MJ, Dohm, DJ, Sardelis, MR, O'Gunn, ML, et al. An update on the potential of North American mosquitoes (Diptera: Culicidae) to transmit West Nile virus. J Med Entomol 2005; 42:57-62.

Wilcox, BR, Yabsley, MJ, Ellis, AE, Stallknecht, DE, Gibbs, SEJ. West Nile virus antibody prevalence in American crows (Corvus brachyrhynchos) and Fish Crows (Corvus ossifragus) in Georgia, U.S.A. Avian Dis 2007; 51:125-128.

Zeller, HG, Schuffenecker, I. West Nile virus: an overview of its spread in Europe and the Mediterranean basin in contrast to its spread in the Americas. Eur J Clin Microbiol 2004; 23:147-156.

Address correspondence to: Guillermo López

Estación Biológica de Doñana Americo Vespucio s/n 41092 Seville Spain

E-mail: guiloza@gmail.com 